DOI https://doi.org/10.36059/978-966-397-169-8/47-67

\title{
EUROPEAN PRACTICES OF ISSUANCE OF STAMPS: HISTORICAL AND CULTURAL ASPECTS
}

\section{Svetlana Oriekhova}

\section{INTRODUCTION}

The postage stamp is a mail stamp or fiscal stamp of a certain value; an evidence of payment of the state postage fee; the sign of the mailings issued by the communication agencies; an artistically designed miniature edition. Postage stamps are also used to promote state achievements in various fields of production, science, culture and sports, etc.

The pictorial content of the postage stamp provides the opportunity to perceive information, which plays an important role in the scientific and cognitive process of state-making activities as well as represents political and economic documents that describe the socio-economic and cultural life of the state as a peculiar means. Accordingly, the history of the postage stamp is presented as a narrative for the visualization of the history and culture of each issuing country, a member of the Universal Postal Union.

While considering national traditions and symbols that are included in the subject line of postage stamps, it is worth to highlight how history and memory have contributed to the formation of characterstate cultural state identification. The artistic postage stamp is not only the subject of collecting and studying of philatelists as an object of art. It is rather a complicated and multifaceted process of comprehension of the artistic and educational space in this context, since it is based on an interdisciplinary general theoretical base and is the object of research of historians, art critics and philosophers.

The phenomenal invention of a method of payment for mail services - the establishment of a postage stamp, has formed "historypolitics-education" triad. For almost two hundred years of the existence, philately has gone beyond admiration and achieved the status of a special historical discipline. 
The subject of philatelic research are postage signs, which include stamps, labels, tag, provisionals, postage grills (calendar and special postmarking of a postage stamps), postmarks, as well as envelopes, postcards and leaflets with these signs printed (postal stationery) or pasted (philatelic cover) and other types of philatelic materials. The subject matter of the study is the history of the postal service of the issuing country. The peculiarities of methodological techniques of the specialized discipline of "philately" are due to the specificity of its sources - carriers of diverse historical information and the uniqueness of the subject of study. According to the subject of study of the history of philately, its main methodological directions include:

- systematization of knowledge about the origin, development, nature and composition of the source base of philatelic history in the world;

- classification of conditions of its operations, internal interaction and external relations;

-development of methodology and methodology of scientific search, study and use of sources from the history of philately.

At the same time, the intensification of national self-identification, a vibrant self-expression of the ethnic component in every national culture, is being intensified.

Therefore, one of the primary tasks is to develop within the diversity of sciences, disciplines, research methods, ideas of clear methodological principles for the study and study of the philatelic area in the context of modern scientific knowledge. The essence of this new concept of history makes it possible to comprehend the vector of the development of the most modern processes in the national art, artistic and creative space, cultural and educational activities.

\section{The evolution of the postage stamp: analysis of thevisual representations in the historical world context}

In the history of mail, the issue of a postage stamp of 1-penny (black) and 2-pence (blue) denominations by the British postal service as well as envelopes of the same denominations and colours marked 1840. The English collectors subsequently called the world's first postage stamp "Penny Black", a small watermark on a small crown, 
the portrait of the Queen of Great Britain, Victoria, is depicted on it ${ }^{1}$. The issue of postage stamps was a direct consequence of the rapid economic development of the most important countries in Europe and, above all, England. The rapid growth of industry caused no less rapid expansion of trade, which, in its turn, led to an increase in mail exchange. A serious obstacle in this direction was the imperfect system of processing mail, disproportionately high postal rates associated with extremely complex calculations. Postal tariffs at that time were set depending on the distance and the number of sheets of which the letter consisted. Full payment for delivery was charged for each sheet of the letter. The minimum tariff in England, for example, was 2 pence. However, depending on the distance and many other factors, sending a letter consisting of only one sheet of paper often cost shilling and a half. These facts were the reason for a member of the English parliament, Samuel Roberts, to issue a pamphlet in which he demanded the establishment of a single rate of 1 penny for all letters, and in 1834, the book dealer and newspaper publisher Charles Knight proposed the issuance of 1-penny envelope for sending newspapers. Both of these proposals were not accepted by the General Post Office. After some time, the Royal Postmaster Rowland Hill returned to the proposals: in his famous leaflet "The Importance and Benefits of Postal Reform" he put forward as the most important task - the establishment of a rate of 1 penny for all letters weighing up to half an ounce (about 14.2 grams). R. Hill believed that the postage should not exceed that amount for simple letters sent within the territory of the United Kingdom, regardless of distance. At the same time, he proposed issuing envelopes, stamped sheets of postal paper and postage stamps for franked letters. This proposal served as the basis for postal reform. The new tariff was specified by the law on January 10, 1840. The cost of sending letters weighing up to $1 / 2$ ounce was set at 1 penny, up to 1 ounce -2 pence and each subsequent full or incomplete ounce - also 2 pence. The maximum weight was set at 16 ounces (approximately

${ }^{1}$ Levitas J. Ya., Basyuk V. (1975) Vse pro marky' [All about brands]. Kiev: Reklama (in Ukrainian). P. 13. 
454 grams $)^{2}$. The drawing on the front side of the envelope obtained by folding the mailing sheet was created by the artist William Mulready who took part in the competition announced by the English Treasury (adopted on May 6, 1840). These envelopes, which have become very rare today, are called "Mulready envelopes"3. Although the first postage stamps appeared in England, other countries used franking notes similar to them much earlier.

Thus, stamped receipts had been in use in Berlin since 1827. In Greece since 1831 official charitable stamps were sold. The Postmaster-General of New South Wales organized the sale of stamped envelopes in 1838. In Sardinia, in 1818, 15-, 25- and 50- centesimo sheets of postal paper were issued with an embossed image of a postman, which corresponded to the cost of private delivery of correspondence to different zones. According to the drawing, these sheets are called "small horses" among the collectors.

At the beginning of the 19th century, there were two methods of collecting postage. In one case, when the sender paid the shipping cost, the letter was called "Paid" or "Franco". If the "Franco" letter was put in the mailbox, the sender should have put there the proper amount of money. In the second case, letters could be sent unpaid; then the postage was paid by the recipient and was called "porto". But all the time there were such cases when letters had to be transported through the several state borders. Each country had its own principles of calculation, its own postal rates. The various tariffs led to the fact that the postal fee for letters addressed abroad, increased disproportionately. The elimination of zones by distance and the convenient franked letters with the usage of postage stamps greatly facilitated the calculation of the amount of postage. Therefore, it is not surprising that the postal administrations of other countries showed a keen interest in the innovation introduced in England. The first one who decided to introduce postage stamps was Zurich cantonal mail

${ }^{2}$ Levitas J. Ya., Basyuk V. (1975) Vse pro marky' [All about brands]. Kiev: Reklama (inUkrainian). P. 16.

3 Grallert V., Grushke V. (1977) Fy'lately'sty'chesky'j slovar' [Philatelic Dictionary]. Moscow: Communicatio. (inRussian). P. 70. 
in Switzerland. In March 1843 they created black colour stamps printed lithographically, and on October 1 of the same year the first postage stamps were issued in the canton of Geneva. The follower of the postal innovation of Switzerland was Brazil. There, the establishment of postage stamps was preceded by the postal reform: letters were distributed by weight category, classification by distance was cancelled; for letters sent by sea mail, a double tariff was established; emigrants' letters sent to their homeland were completely postage free. Thus, it was established mandatory prepayment of postage - the system that most countries do not currently use. Along with the rules for franked letters, Brazilian decrees provided for the payment for stamps using a postmark. Thus, on August 1, 1843, the first postage stamps appeared in Rio de Janeiro, which later received the name "bull eyes" from philatelists. Postmaster Henry Bishop, who in 1661 for the first time used a stamp to fix the route and time (duration) of the mailing, introduced the world's first postal stamp in England ${ }^{4}$.

In subsequent years, franking notes (postage stamps and envelopes, as well as postmarks as a way of paying for the stamps) were actively adopted in many countries of the world. Sometimes these were stamps, such as in Basel (01.07.1845) or on the island of Mauritius (01.10.1847), and sometimes envelopes with a stamp. Today, these stamps are extremely rare: they are rarities in philately and their auction value amounts to tens of millions of dollars.

Periodization of the introduction of postage stamps:

1843 - Cantons of Zurich and Geneva in Switzerland, Brazil;

1847 - USA (5-cent red-brown stamps with the image of Benjamin Franklin and 10-cent black stamps with the image of George Washington);

1849 - France (20-, 40-centime and 1-franc stamps are known under the name "Ceres" with the image of the goddess of agriculture); Belgium (10-, 20-centime denomination, the Epaulet series with a portrait of Leopold I) and Bavaria (received the name "Black unit");

4 Grallert V., Grushke V. (1977) Fy'lately'sty'chesky'j slovar' [Philatelic Dictionary]. Moscow: Communicatio. (inRussian). P. 14. 
1850 - Austria (Austrian territory of Lombardy-Venice, 5-centesimo Queen Isabella II, the inscriptions "correos" (mail) and "franco" (payment), the name of the state was denomination); Spain (image of not indicated); New South Wales and Victoria (first stamps of Australia); Saxony (3-pfennig denomination - "The Sachsen 3 Pfennige red"; Prussia (6-pfennig, 1, 2- and 3-zilbergrosh denominations, image of Friedrich Wilhelm IV) and others;

1851 - Sardinia (a series of three stamps with the profile of King Victor Emmanuel II); Denmark (4-Ricksbankskilling denomination, royal regalia in a laurel wreath); Canada (3-pence stamp "Threepenny Beaver");

1852 - Papal region (the series consisted of eight miniatures of various denominations from $1 / 2$ - to 7 -baiocco. Image of the papal coat of arms - crossed keys of St. Peter and the papal tiara); the Netherlands (nominal value of 5 cents, image of King Willem III, William III, Willem Alexander Paul Frederick Lodewijk), mail Turn and Taksis (the first stamp from the first issue for the North German states was with a value of Silbergroschen);

1853 - Cape of Good Hope (the first stamp of Africa) (1-penny, 4- and 6-pence, 1-shilling denominations, the figure of a woman with naked breasts at the ship's anchor was depicted - an allegory of hope, philatelic name "primitive marks of the Cape colony, the first triangular marks in the world);

1854 - India (they started to use stamps in Sindh province, in the centre of the stamp there was a traditional trademark of the British East India Company);

1857 - Russian Empire (a detailed description is presented below);

1861-1863 - Italy (the first series of 8 stamps of the Kingdom of Italy with from 1-centimesimo to 2-lira nomination were adopted on December 1,1863 . The stamp value in a curly frame was depicted on 1-centezimo miniature, portrait of the king Victor Emanuel II and the inscription "Poste italiane" were depicted on the rest stamps);

1866 - Egypt (text in Arabic and Masri, the outline had oriental ornament);

Honduras (the coat of arms of the country and the name of the state "Correos de Honduras" (post of Honduras) was depicted. There is 
doubt in the philatelist community that these stamps received by mail); Serbia (three miniatures with a portrait of Prince Michael III and the inscription "K. Serbian post" in Serbian);

1868 - Iran (imperforated stamps depicting a heraldic lion were printed in Tehran from those made in Paris, they were used only in Tehran, Qazvin, Zinjan and Tabriz);

1871 - Japan (series of 4 stamps, denominations indicated in mona, two-colour drawing consisted of a pair of dragons facing the centre where hieroglyphs representing the denomination were printed); Hungary (series of six stamps, miniatures with a portrait of Emperor Franz Joseph I and the coat of arms of the Kingdom of Hungary);

1872 - Germany (Deutsche Reichspost was officially established on May 4, 1871, the first stamps of imperial mail was adopted);

1878 - China (image "big dragon", the inscription "CHINA" in Latin and Chinese characters, the denominations on the stamps were indicated in kandarin);

1879 - Bulgaria (stamps of five denominations in French currency from 5 to 80 centimes, image - reproduction of an old Bulgarian symbol, a standing lion);

1984 - Abyssinia (Ethiopia) (on the stamps of four lower denominations, Menelik II was depicted wearing the coronation crown, on the other three stamps of higher denominations there was the image of the heraldic Leo from the tribe of Judah. The name of the country was indicated in Amharic, the denominations of stamps were are from $1 / 4$ to 16 gersh).

Thus, technological progress, the development of foreign relations between the countries of the world increased, as well as the culture of correspondence encompassed wide sections of the country's population, thereby postal service expanded its borders and became an affordable means of communication both within the state and far beyond its borders.

In Russia, the postage stamp appeared much later. However, it was preceded by such events - the first signs of postal payment were introduced by Russian mail in the form of stamped envelopes. On January 1, 1845 in Finland they were used for the whole principality, which was then a part of the Russian Empire; December 1, 1845 - for 
the Metropolitan, St. Petersburg City Post Office and, finally, on December 1, 1848 - for foreign correspondence throughout the country.

The project of introduction of stamped stamps (original name) belonged to the head of issues of mail transportation by train O. P. Charukovsky. Preparation for the introduction of postage stamps in Russia began in 1852. The Russian State Historical Archives in St. Petersburg funds contain letters from the Director of the Postal Department, F. I. Pryanishnykov, to the Prussian Post Director regarding the experience of franked correspondence using postage stamps ${ }^{5}$.

In 1856, trial sketches of stamp stamps were made under the direction of Ya. A. Reichel, head of the printing department of the Securities Procurement Expedition (St. Petersburg), but the samples were not approved. Later, a new drawing of the future Russian rectangular postage stamp was created by F. Kepler, an engraver of Securities Procurement Expedition. In November 1856, the State Council considered the project on the issue of stamps, and a year later in November 1857 the project was approved. The design, the form and the name of the mark were also approved, instead of the "stamped" it was named "postal".

In January 1858, Russia's first postage stamp, with a nominal value of 10 kopecks, was adopted ${ }^{6}$. The first issue of Russian stamps was published in the State Paper Procurement Expedition with a total circulation of 3.0 million copies. One printed sheet contained one hundred units of stamps, without perforation. The stamp had a rectangular shape, an inner oval, in the form of a medallion, blue with a white embossed state emblem of the Russian Empire and postmarks - cross horns. The medallion was surrounded by a mantle crowned with a crown, under the mantle there was an inscription "10 kopecks per an item" (10 kop. za lot), in the corners the

${ }^{5}$ Oriekhova S. (2006) Istorija rozvytku poshtovogho zv'jazku u Donecjkij oblasti XIX-XXI st. [History of postal service development in Donetsk region, XIX - XXI centuries]. (PhD Thesis), Donetsk: DonNU. C. 60.

${ }^{6}$ Russian State Historical Archives in St. Petersburg f. F. 1289, op. 13, spr. 1249. 
denomination of mark "10" was determined with the Arabic numerals. Subsequent issues of the stamps were perforated. Stamps were issued in 10-, 20- and 30- kopeck denominations. For the 60-year period (1857-1917), one hundred and thirty-three varieties of Russian postage stamps were issued, which usually differed in colour and perforation, but the plot remained unchanged. Only three series of stamps had distinct differences: two charities (1905 and 1914 issuance) and one anniversary (1913 issuance $)^{7}$.

Since 1864, postal items sent abroad were paid for by postage stamps. To this end, the Post Office Department issued a circular "On franked foreign correspondence with postage stamps", on the basis of which, in addition to the existing ones, 1-, 3- and 5- kopeck stamps were introduced ${ }^{8}$. In March 1872, the first open, so-called light letters, now known as postcards, went on sale in Russia. The front of the card contained some place intended only for the address, the back side - for the written message itself. From May 1872 there were postcards with stamps printed on them (3-kopeck one - within the city limits, 5-kopeck one - long distance transportation) ${ }^{9}$.

Thus, these transformations have significantly affected the socioeconomic life of the countries of the world. This, in turn, required postal services administrations to further improve their postal services, such as achieving speed and regularity, expanding the network of postal and subsequently postal and telegraph institutions, expanding the range of services and reducing the cost of services, and so on.

The history of the Ukrainian postage stamp is multifaceted: there are many landmark, attractive and poorly researched pages that also deserve review and research. With the proclamation of the Ukrainian People's Republic as an independent state, in the spring of 1918, the first five postage stamps of the UPR were established, the authors of

${ }^{7}$ ZagorskyB., KirzhnerI. (2009) Katalog pochtovykh marok Rossii 1857-1991. Rossii, RSFSR, SSSR: katalog-spravochnik [Catalog of Russian Postage Stamps 1857-1991. Russia, RSFSR, USSR: Directory-Directory]. St. Petersburg: Standard Collection. (in Russian) P. 12-20.

${ }^{8}$ Russian State Historical Archives in St. Petersburg f. F. 1289, op. 23, spr. 300.

${ }^{9}$ Russian State Historical Archives in St. Petersburg f. F. 1275, op. 1, spr. 26. 
which were famous Ukrainian artists Antin Sereda and Georgy Narbut. Miniatures in allegorical form depict national symbols of Ukraine. The cost of the stamps was set in monetary units - "shagi", therefore they were called "stamps-shagivky". The first postage stamps of the Western Ukrainian People's Republic also performed communicative functions. During the short time of its existence, the postage stamps of the UPR and WUPR (1917-1920) have gained popularity among European collectors and have become the object of study and cataloguing. In the USSR, their own Ukrainian postage stamps were not issued, although since 1947 the republic was a member of the Universal Postal Union. After Ukraine's declaration of independence, the production of its own postage stamps began in 1992, which for over a quarter of a century has been the unique postal attribution fund of the country. Annually, starting from 1997, stamps, blocks on the common theme of the regional organization of post administrations of the European countries - Post Europare issued. And in 2001 also the mark "Dialogue of civilizations" was issued, the same in the drawings for all the Member States of the UPU, which had participated in the simultaneous release of such stamps on World Mail Day ${ }^{10}$. It should be noted that Ukraine has been a full member of the UPU since June 1947. This fact is confirmed by the circular of the Director of the Swiss UPU Confederation, Mr. Muri, signed on May 30, 1947, which states the accession of the Ukrainian Soviet Socialist Republic to the Universal Postal Convention. During the XXIUPU Congress in 1994 in Seoul, Ukraine was elected to the Governing Body, which defines the authority of the state in the world community ${ }^{11}$.

Thus, in the process of studying the formation and development of European stamp issuance in the period from XVIII-XXI centuries, it should be noted that government tariff policies facilitated the

10 Kramarenko M. (2011) Ukrayna. Katalog hpochtovikh marok 1866-2010 [Ukraine. Stamp catalog 1866-2010]. Donetsk: "The New World" (in Ukrainian)

11 Oriekhova S. (2017) Ukrayina u svitovomu filatelisty'chnomu prostori [Ukrainein the world philatelic space]. Proceedihg of the Ukrayina $u$ svitovomuistory'chnomu prostori (Ukrayina, Mariupol, April21, 2017) (eds. Balabanov K.), Mariupol: MDU, pp. 278-282. 
establishment of postal items (stamps, envelopes, cards). This led to an increase in postal exchanges, the collection of postal items, and the establishment of the World Postal Union, which facilitated the establishment of international postal arrangements.

\section{The role of the Universal Postal Union in the development of a worldwide philatelic strategy}

Among the communication methods and means of sending and delivering messages, postal service is perhaps the oldest. For centuries, the postal service has developed for the long time. It is inseparable from the origin and formation of terrestrial civilizations, and history and development of postal service have always come along ${ }^{12}$.

Mail promotes the institutionalization of the principles of international communication. Significant milestones in the history of the world mail were the expanding shipment of postal correspondence from one country to another, the growth of transit traffic of international postal items of various types. By the mid-19th century it was high time to establish the legal provisions of international legal relations and maintain simplification of the system of tariffs and mutual calculations. With the formation of the Universal Postal Union, the obstacles that divided the nations for millennia and hindered the process of their rapprochement, were removed.

The World Postal Union was founded on the basis of the GermanAustrian Postal Union, founded in 1850. The imperial royal postal controller Joseph Hecht initiated the first proposal for the development of the "universal European postal law". In his book, which was released in 1749 , he made an attempt to unify the numerous, sharply different tariffs of German post offices. Only a hundred years later, on April 6, 1850, the first treaty was concluded in Berlin, which equalized the rights of various German postal offices and laid the foundation for the German-Austrian postal union. In 1859, the idea of creating an international postal organization was put forward by a Danish official,

12 Oriekhova S. (2006) Istorija rozvytku poshtovogho zv’jazku u Donecjkij oblasti XIX-XXI st. [History of postal service developmentin Donetsk region, XIX - XXI centuries]. (PhD Thesis), Donetsk: DonNU. C. 5. 
Josef Michaelsen. At the initiative of the US General Postmaster Mongomery Blair in 1863, a conference of representatives of the postal administrations of 17 European countries and the USA was held in Paris. Several resolutions were adopted, some principles of the work of the future organization were formulated, but the conference did not have practical results. A few years later, Heinrich von Stefan (since 1870 the Director General of the North German Postal Union) and Eugene Borel (Swiss politician who contributed to the creation of the Swiss Postal Union and the conclusion of the Universal Single Postal Agreement) proposed to establish the Universal Postal Union ${ }^{13}$. In 1873, the postal union of European states was created in Berlin. On September 27, 1874 in Bern (Switzerland), an agreement on the organization of the Universal Postal Union was signed with the participation of Russia ${ }^{14}$.

The Universal Postal Conference was opened with the participation of 38 representatives from 22 countries, and on October 8, the Universal Postal Convention was concluded. Representatives of participating countries, including Austria-Hungary, Belgium, Great Britain, Germany, Italy, Norway, Russia, Serbia, USA, Switzerland and Sweden, signed it. The conference resulted in adoption of the unity of the postal territory, postal rate and balancing of postal charges, on complete freedom and, if possible, free transit. On October 9, the congressional conference proclaimed the creation of the Union Postal Universally (UPU).

The legislatures of the Universal Postal Union called for international postal congresses every five years. The executive body of the union became the International Bureau in Bern. The governments of the participating countries have ratified all decisions of the congress. For the first time, the international body had established uniform rules for sending mail and simplifying international mail exchanges.

${ }^{13}$ Grallert V. (1965) Puteshestvy'e bez vy'z. Kny'ga o pochte y' fy'lately'y' [Travel without visas. A book about mail and philately]. Moscow: Communicatio. (in Russian). P. 68.

${ }^{14}$ Russian State Historical Archives in St. Petersburg f. F. 1289, op. 13, spr. 119. 
Subsequent international congresses took place in different member states: Paris (1878), Lisbon (1885), Washington (1897), Rome (1906), Madrid, where the conference had to be taken in 1913, but it failed because of the international situation ${ }^{15}$. The Congresses improved and simplified the procedure for sending various types of correspondence, reduced tariffs, regulated financial settlements, resolved disputes between member countries of the Universal Postal Union, and accepted new members into the union. Thus, during the Paris Congress, a system of international money orders was introduced. At the Congress in Vienna, all the resolutions of existing international postal agreements were revised. The projects on subscribing to time-based publications at the postal institutions were approved as well as the establishment of the Central Accounts Office, which took charge of transit shipments between states, were adopted (previously those calculations were carried out by sending cash between governments).

Today, the Universal Postal Union is one of the largest international organizations operating under the United Nations auspices. The UPU currently consists of 189 member states. The UPU forms a single postal area for the member states $t$. The legal basis of the Union is a set of legal documents, the main of which is the Charter. General Regulations are the legal ground for the Statute. The supreme governing body of the UPU is the World Postal Congress, which meets once every five years. The governing bodies of the UPU are the Administrative Council and the Postal Operations Council ${ }^{16}$. The UPU is responsible for promoting harmony and communication between nations, using optimized international mail exchange management systems, and supporting the work of the World Philatelic Association.

Its core responsibilities include protecting respect for the cultural and national identity, as well as the ethics of Member States, based on the understanding that the postage stamp is a means of promoting the image of the country as it serves as a travelling ambassador getting around the world.

\footnotetext{
${ }^{15}$ Russian State Historical Archives in St. Petersburg f. F. 1289, op. 2, spr. 1.

${ }^{16}$ Knyazyeva N., Gorelkina S., Ivanov V., Kuzneczova L. Markety'ng poshtovogo zv'yazku [Mail marketing]. Kiev: TOV "Vy'davny'cztvo “Aspekt-Poligraf" (in Ukrainian). P. 39.
} 
Stamp collecting is influenced by many factors. With the reference to the fact that the responsibility for ensuring the success of philately is shared, this is the basis for the philatelic sector and postal administrations to form an association for many years. In the early 1990s, philatelic partners (states) made great efforts to promote dialogue and engagement. States' postal administrations have made a major contribution to the creation of the UPU Contact Committee with the Philatelic Associations. With the acknowledgement of the importance of the association, in 1999 the Beijing Convention authorized the restructuring of this committee into the World Philatelic Development Association (WADP) ${ }^{17}$. Today WADP is a branch of the UPU, which is subordinate to the Postal Operations Council (POC).

It is a strategic forum whose activities provide the postal administrations and their philatelic partners (agents, collectors, brand dealers and specialized media) with the possibility to cooperate, to protect the integrity of postage stamps, as well as to develop and promote philately around the world.

Table 1

Members of the World Philatelic Development Association

\begin{tabular}{|l|c|l|}
\hline Postal administrations & UPU & \multicolumn{1}{|c|}{ The Universal Postal Union } \\
\hline Specialized media & AIJP & $\begin{array}{l}\text { The International Association } \\
\text { of Philatelic Journalists }\end{array}$ \\
\hline $\begin{array}{l}\text { StampCatalogues } \\
\text { and albums }\end{array}$ & ASCAT & $\begin{array}{l}\text { The International Association } \\
\text { of Publishers of Stamp } \\
\text { Catalogues, Albums, and } \\
\text { Philatelic Magazines }\end{array}$ \\
\hline Collectors & FIP & $\begin{array}{l}\text { The Fédération Internationale } \\
\text { de Philatélie }\end{array}$ \\
\hline Stamp Dealer & IFSDA & $\begin{array}{l}\text { International Association } \\
\text { of Stamp Dealer Associations }\end{array}$ \\
\hline $\begin{array}{l}\text { Printing stamps } \\
\text { printers }\end{array}$ & $\begin{array}{l}\text { INTER- } \\
\text { GRAF }\end{array}$ & $\begin{array}{l}\text { International Confederation } \\
\text { for Printing and Allied Industries } \\
\text { (INTERGRAF) }\end{array}$ \\
\hline
\end{tabular}

${ }^{17}$ World Postal Union (1999) Konvenciya Vsesvitn'ogopo shtovogo soyuzu [World Postal Union Convention]. Beijing: World Postal Union. 
The tasks of World Association for the Development of Philately (WADP) are as follows:

- promoting the development of philately and reviving it and collecting stamps as a major hobby;

-capture and support interaction between all key agents in the philatelic sector;

- supporting the implementation of a stable philatelic strategy worldwide.

The general provisions of the UPU provide that only postal administrations issue postage stamps confirming the payment of postal items according to the UPU. The themes and design of the postage stamps correspond to the spirit of the Preamble to the Statute of the UPU and the decisions taken by the Union bodies. The guidelines also require postal administrations to report new issues and exchange stamps to each other through the UPU International Bureau. Another guideline specifies the requirements for postage stamps, country names, denominations, and specifies their size and the use of punching. Article 8 of the UPU Convention specifies all orders of the UPU concerning postage stamps ${ }^{18}$. It describes in particular the activities of the postal administrations concerning the development of the philatelic area, the Code of Philatelic Ethics of the UPU.

The Code of Ethics is a key element in guidance of postal administration according to the question of development and growth of philatelic enthusiasm that raises trust in collecting in the country and the world.

Ukraine has become a full member of the UPU since June 1947. To join the UPU, Ukraine adopted the UPU Charter. As an independent state and a member state of the UPU, Ukraine has been a postal stamp issuer since $1992^{19}$.

\footnotetext{
${ }^{18}$ World Postal Union (2008) Konvenciya Vsesvitn'ogo poshtovog osoyuzu [World Postal Union Convention]. Geneva: World Postal Union.

19 Oriekhova S. (2017) Ukrayina u svitovomu filatelisty'chnomu prostori [Ukrainein the worldp hilatelic space]. Proceedihg of the Ukrayina $u$ svitovomu istory'chnomu prostori (Ukrayina, Mariupol, April21, 2017) (eds. Balabanov K.), Mariupol: MDU, pp. 278-282.
} 
However, the history of philately in Ukraine is inextricably linked to the world of philately. Based on catalogued issuance of postage stamps of Ukraine (1866-2019), a periodization of the history of philately of Ukraine in the context of world development is presented below (Table 2$)^{20}$.

Table 2

\section{The History of Philately}

\begin{tabular}{|c|l|}
\hline $\begin{array}{c}\text { late XVIII s. - } \\
\text { up to 1838 }\end{array}$ & $\begin{array}{l}\text { Collecting fiscal (emblem) stamps and signs that gave the } \\
\text { right to forward correspondence (lettering). The right } \\
\text { specify exemption from payment of postage. Issue of the } \\
\text { first philatelic cover with paid postage. } \\
\text { Before the existence of postage stamps on the territory of } \\
\text { the Carpathian Ukraine (up to 1850), Left Bank Ukraine, } \\
\text { Slobidska Ukraine and Southern Ukraine (up to 1857) }\end{array}$ \\
\hline \multirow{3}{*}{1840} & $\begin{array}{l}\text { Global trend is issue of the first postage stamps and one- } \\
\text { piece items with paid postage for shipment within the } \\
\text { country. }\end{array}$ \\
\hline The $1850 \mathrm{~s}$ & $\begin{array}{l}\text { The establishment of the first catalogues encourages the } \\
\text { collection of postage stamps and philatelic cover. State } \\
\text { stamps of the Russian Empire (since 1857). }\end{array}$ \\
\hline the 1860 s - $1870 \mathrm{~s}$ & $\begin{array}{l}\text { The first exposuring of the collections is organized. } \\
\text { Austrian issues of postage stamps on the territory of the } \\
\text { Carpathian Ukraine (1850-1871), postage stamps of the } \\
\text { Ukrainian districts on the territory of Left Bank Ukraine, } \\
\text { Slobidska Ukraine and Southern Ukraine (1866-1917) }\end{array}$ \\
\hline the 1890 s & $\begin{array}{l}\text { There is establishment of philately (collecting traditional } \\
\text { postage stamps and philatelic cover). State stamps of the } \\
\text { Russian Empire (1857-1917). }\end{array}$ \\
\hline early XX century & $\begin{array}{l}\text { Exposuring of postage stamps is becoming more popular, } \\
\text { especially in Europe. }\end{array}$ \\
\hline \multirow{2}{*}{ the $1910 \mathrm{~s}$} & $\begin{array}{l}\text { There is less interest in collecting philatelic cover as they } \\
\text { are no longer catalogued. It caused difficulties in tracking } \\
\text { official issues of them. }\end{array}$ \\
\hline
\end{tabular}

${ }^{20}$ Oriekhova S. (2019) Filateliya - suchasny'jrux v istory'chnijnauci [Philately - a modern movement in historical science]. Proceedihg of the Modern science movement (Ukrayina, Dnieper, April 4-5, 2019) (eds. Vysotsky O.), Dnieper, SPD "Hunter", pp. 823-827. 
Continuation of Table 2

\begin{tabular}{|c|l|}
\hline & $\begin{array}{l}\text { Proliferation of the use of postcards and creation of } \\
\text { decorative (commemorative) stamps lead to the } \\
\text { emergence of maximophilia (collecting and studying of } \\
\text { the maximum cards). These are postcards with the } \\
\text { appropriate stamp of special redemption. The main factor } \\
\text { is that all the components, the card itself and postage } \\
\text { stamp should be consistent with each other). This branch } \\
\text { of philately is popular in France, Netherlands, Belgium, } \\
\text { Poland, Romania, USSR and Ukraine. } \\
\text { the 1910s s }\end{array}$ \\
\hline \multirow{1}{*}{ Czechoslovak issuanceon the territory of the Carpathian } \\
Ukraine (1918-1939)
\end{tabular}


Completion of Table 2

\begin{tabular}{|c|l|}
\hline the $1980 \mathrm{~s}$ & $\begin{array}{l}\text { Contemporary competition categories are being } \\
\text { developed. The particular growth of philately in Asia }\end{array}$ \\
\hline \multirow{2}{*}{ the $1990 \mathrm{~s}$} & $\begin{array}{l}\text { The establishment of two new categories of philately: } \\
\text { emblem stamps and experimental social philately. Stamp } \\
\text { exposuringis spreadwith the use of asingle frame. FIP is } \\
\text { expanding, and worldwide exhibitions are becoming more } \\
\text { and more numerous. }\end{array}$ \\
\hline $\begin{array}{l}\text { The late } 1990 \mathrm{~s}- \\
\text { present moment }\end{array}$ & $\begin{array}{l}\text { The formation of the WPDA (World Philatelic } \\
\text { Development Association) as a new means for } \\
\text { strengthening philately. } \\
\text { State issuance of independent Ukraine }\end{array}$ \\
\hline
\end{tabular}

Therefore, postage stamps are the means of reflecting the country's most valuable heritage and cultural perspectives around the world. The condition and development of philately demonstrates the level of the civilization of the society.

\section{CONCLUSIONS}

Comprehensive study of the sources and literature leads to the conclusion that the genesis of state identification, with the assistance of stamp issuance, is a relevant topic. Thus the choice of the object of study - postage stamps of the first half of the XIX century - beginning of the XXI century as sources of historical memory - is a major element of the scientific novelty. Based on the principles of historical science, such as historicism, objectivity, dialectical principle, with the use of complex, chronological and statistical methods, an attempt to perform a comprehensive analysis of the processes of issue, adopt of postage stamps of the leading states of the world, which are States Parties to the World postal union, is made. In the process of the research of the stated purpose, the following conclusions can be stated.

The issue of postage stamps has been a particularly progressive phenomenon in public administration and the economy, and it has acquired artistic and cultural significance in the world history of philately. Over time, the postage stamp has gone from the direct obligation of the postal administration to the sender, to the formation 
of a source of historical memory and worldview. The modern functions of the postage stamp are:

- economic - the cost of postal services indicated on the mark is the economic component of the state;

- monetary - monetary functions of postage stamps;

- formation of the monetary system of the state;

- attributive - symbols of state identification are depicted on it coat of arms, national currency which contain information about the country as a political statement of state sovereignty;

-advertisement and information - as a method of stimulating interest to the problems of a social nature, the world, charity, etc.;

- collectible - it has both intrinsic and actual value, which can be very different from its postal value. This function is a direct consequence of the development of philately as a hobby spread worldwide;

- cultural - as an art miniature, containing decorative elements and dedicated to a specific subject.

The postage stamp promotes the historical and cultural heritage of the state and it is an effective carrier of its axiological code.

\section{SUMMARY}

Thus, the postage stamp is not just an art miniature through which we look at the past historical reality. It is the most convenient matrix for mastering the ability to relate history as historiographical text with a narrative representation of the past.

The postage stamp is not only a form of payment for services, but also a visualization of the history and culture of each state. Such a miniature thing as the postage stamp is informative. It serves as a marker of events, captures and engraves them on the pages of historical and cultural memory. Without historical memory, each society's history cannot be reproduced. It is an inheritance of the past experience, and it exists in the form of the historical consciousness of the people, embodied in appropriate cultural forms.

Postage stamps, as an element of statehood, represent political and economic documents, which in a peculiar way fixed the socioeconomic and cultural life of the states and formed the basis of modern stamp issuance. 


\section{REFERENCES}

1. Grallert V. (1965) Puteshestvy'e bez vy'z. Kny'ga o pochte y' fy'lately'y'[Travel without visas. A book about mail and philately]. Moscow: Communicatio. (in Russian)

2. Grallert V., Grushke V. (1977) Fy'lately'sty'chesky'j slovar' [Philatelic Dictionary]. Moscow: Communicatio. (in Russian)

3. Knyazyeva N., Gorelkina S., Ivanov V., Kuzneczova L. Markety'ng poshtovogo zv'yazku [Mail marketing]. Kiev: TOV "Vy'davny'cztvo “Aspekt-Poligraf" (in Ukrainian)

4. Kramarenko M. (2011) Ukrayna. Katalog hpochtovikh marok 1866-2010 [Ukraine. Stampcatalog 1866-2010]. Donetsk: "TheNewWorld" (in Ukrainian)

5. Levitas J. Ya., Basyuk V. (1975) Vse pro marky' [All about brands]. Kiev: Reklama (in Ukrainian)

6. Oriekhova S. (2006) Istorija rozvytku poshtovogho zv'jazku u Donecjkij oblasti XIX-XXI st. [History of postal service developmentin Donetsk region, XIX - XXI centuries]. (PhD Thesis), Donetsk: DonNU.

7. Oriekhova S. (2019) Filateliya - suchasny'jrux v istory'chnijnauci [Philately - a modern movement in historical science]. Proceedihg of the Modern science movement (Ukrayina, Dnieper, April 4-5, 2019) (eds. Vysotsky O.), Dnieper, SPD "Hunter", pp. 823-827.

8. Oriekhova S. (2017) Ukrayina u svitovomu filatelisty'chnomu prostori [Ukrainein the worldp hilatelicspace]. Proceedihg of the Ukrayina u svitovomu istory'chnomu prostori (Ukrayina, Mariupol, April 21, 2017) (eds. Balabanov K.), Mariupol: MDU, pp. 278-282.

9. Russian State Historical Archives in St. Petersburg f. F. 1275, op. 1, spr. 26.

10.Russian State Historical Archives in St. Petersburg f. F. 1289, op. 2 , spr. 1.

11.Russian State Historical Archives in St. Petersburg f. F. 1289, op. 13, spr. 119.

12.Russian State Historical Archives in St. Petersburg f. F. 1289, op. 23 , spr. 300 . 
13.World Postal Union (1999) Konvenciya Vsesvitn'ogo poshtovogo soyuzu [World Postal Union Convention]. Beijing: World Postal Union

14.World Postal Union (2008) Konvenciya Vsesvitn'ogo poshtovogo soyuzu [World Postal Union Convention]. Geneva: World Postal Union

15.Zagorsky B., Kirzhner I. (2009) Katalog pochtovykh marokRossii 1857-1991. Rossii, RSFSR, SSSR: katalog-spravochnik [Catalog of Russian Postage Stamps 1857-1991. Russia, RSFSR, USSR: Directory-Directory]. St. Petersburg: Standard Collection. (in Russian)

\section{Information about the author: Svetlana Oriekhova,}

$\mathrm{PhD}$ in History, Associate Professor, Doctoral Student at the Department of Historical Disciplines, Associate Professor at the Department of Cultural Studies and Information Activity, Mariupol State University 12, Budivelnykiv Ave, Mariupol, 87500, Ukraine ORCID ID: orcid.org/0000-0001-9303-4469 